\title{
Development of Preparedness Competencies in Basic Education Science Curriculum: An Insight from the COVID-19 Global Outbreak
}

\author{
Michael Bobias Cahapay ${ }^{1 *}$
}

${ }^{1}$ College of Education, Mindanao State University, General Santos City, PHILIPPINES

*Corresponding Author: mbcahapay@up.edu.ph

Citation: Cahapay, M. B. (2021). Development of Preparedness Competencies in Basic Education Science Curriculum: An Insight from the COVID-19 Global Outbreak. European Journal of Environment and Public Health, 5(1), em0063. https://doi.org/10.29333/ejeph/8578

\begin{tabular}{|c|c|}
\hline ARTICLE INFO & ABSTRACT \\
\hline Received: 9 Jun. 2020 & The Coronavirus Disease 2019 (COVID-19) has caused an extraordinary crisis that affects educational systems. \\
\hline Accepted: 30 Jul. 2020 & $\begin{array}{l}\text { This editorial letter calls for the development of preparedness competencies as part of the basic education science } \\
\text { curriculum. It discusses the background from which the current call is hinged, contemporary place of } \\
\text { preparedness competencies in the basic education science curriculum, and possible actions for curriculum } \\
\text { development. This call hopes to open windows of opportunity for the consideration of preparedness } \\
\text { competencies as part of the basic education science curriculum. }\end{array}$ \\
\hline
\end{tabular}

Keywords: preparedness competencies, science curriculum, basic education, curriculum development, COVID19 pandemic

\section{Dear Editor,}

The COVID-19 is a communicable viral infection caused by a new strain of severe acute respiratory syndrome coronavirus (Shereen et al., 2020). It originated in Wuhan, China, and has now spread across six continents and in more than a hundred countries. As world health care systems concentrate resources into research about COVID-19 control and treatment, emerging data are released daily (McLeod, 2020).

This COVID-19 crisis has affected an estimate of more than a billion students (The International Association of Universities, 2020) across the globe. The continuing disease crisis caught the vulnerable group of school children off guard. Admirable efforts from individuals and entities to educate children on how to stop the spread of the disease has been done (Wagner, 2020; Miller, 2020; The Emily Post Institute, 2020; Centers for Disease Control and Prevention, 2020; World Health Organization, 2020).

While this COVID-19 period became a teachable moment, such efforts to teach children also reveal serious gaps in the curriculum within particular attention to preparedness. The concept of preparedness is defined as "the ability of governments, professional response organizations, communities, and individuals to anticipate and respond effectively to the impact of likely, imminent or current hazards, events or conditions" (Humanitarian Response, 2020). It does not only cover large scale capacity but also individual level capacity, including those who are vulnerable like school children.

Within the context of education, most current studies related to COVID-19 and curriculum are focused on the immediate need to shift instructional implementation to distance, online modality (e.g. see Bao, 2020; Birkun, 2020). Much of the current school guidance efforts related to the present crisis focus on practical preparedness such as staying at home, practicing new etiquettes, washing hands, and increasing social distance (Anderson, 2020). However, in the long run, there is a need to intentionally incorporate preparedness as a set of competencies in the curriculum.

The concept of competencies originally refers to is a set of knowledge, skills, and values (Hayes, 1979) that are expressed as curriculum goals. Within the context of preparedness competencies, an example from the work of Gebbie et al. (2013) is stated as "employ protective behaviors according to changing conditions, personal limitations...” (p. 225). The structure shows a performance that is intended to be developed to the target learners. It can be followed in formulating preparedness competencies in the context of global disease outbreak.

The competencies in the context of preparedness are constantly being developed in higher education fields (e.g. see Markenson et al., 2006, Schultz et al., 2012, Smith et al., 2013 in public health professions; King et al., 2015 in psychiatry; Ng, 2012, Maripe \& Sinkamaba, 2014 in social work; Kaslow, 
2004 in psychology; Uhernik, 1998 in counseling). This is understandable because most of these professions serve as the forefronts in disasters, emergencies, and diseases. There has also been a call to develop it in the teacher education (Cahapay, 2020).

It can be further maintained that preparedness competencies have a relevant space in the basic education science curriculum. The subject of science has been a launching pad for emerging social issues and is one of the critical focus for stakeholders in public education in the last two decades (Erdogan \& Stuessy, 2015). If these claims are to be pursued, then the development of preparedness competencies, which likewise stem from the current social issue and are a public concern, has a primary space in the basic education science curriculum.

Furthermore, if preparedness competencies within the context of diseases is to be developed in the basic education science curriculum, it should be appropriately formulated and integrated in all the levels of $\mathrm{K}$ to 12 education with respect to the nature of children based on age groups. There are pieces of scholarly evidence that indicate the appropriateness of children developmental capacity (Pfefferbaum, Pfefferbaum, \& Van Horn, 2018) and children social role in processes that engage them in preparedness such as disaster preparedness (Anderson, 2005).

Schools have essentially integrated preparedness competencies into the curriculum for children. It is currently in the basic education science curriculum in most counties such as the Philippines (Valencia et al., 2018). It should be noted, however, that the current focus of preparedness is understandably within the context of natural disasters. As preparedness is also still a vague concept (Nelson et al., 2007), there is a need to contextualize when it comes to disease emergencies like the COVID-19 global outbreak.

Since preparedness as a concept appears to be an unexplored terrain and especially in the current context of disease crisis, there is a need to formulate them from the scratches. Many curriculum development initiatives in different domains and contexts offer glimpses as to the methods in formulating competencies. These methods are systematic review, situational analysis, and expert validation.

A systematic review employs a set of structured techniques to gather secondary materials, analytically assess them, and synthesize the results (Armstrong et al. 2011). It has been used in competencies formulation (Hsu et al., 2006). The situational analysis is also an essential component and process of curriculum organization (Print, 1993). It has been applied to contextualize competencies (Offorma, 2016).

Moreover, the preparedness competencies generated from one or a combination of systematic review and situation analysis will require expert validation. Matton (2005) referred to this process of expert validation as "knowledge extraction" which is a technique of obtaining technical information from subject matter experts in the formulation of the competencies.

Once the preparedness competencies have been formulated, there are curriculum approaches that facilitate their sound integration. These approaches are separate course approach, skill intensive approach, selective emphasis approach, and across curriculum approach (Glatthorn et al.,
2016). There are no empirical studies as regards the approach that works best to integrate competencies. Glatthorn et al. (2016) advised to carefully assess the teacher capacity, nature of current curriculum, instructional resources, and learner interest.

The COVID-19 is undeniably changing the educational landscape across the world. One of the calls responding to the emerging educational changes is the development of preparedness competencies in the basic education science curriculum. The science curriculum has always served as an introductory pad for emerging educational changes, thus a strategic subject for preparedness competencies for school children. Some cogent approaches rooted in curriculum development practice offer means as regards the development of preparedness competencies. This paper is desired to open windows of opportunity for the development of preparedness competencies as a part of the basic education science curriculum.

\section{REFERENCES}

Anderson, A. (2020, March 20). COVID-19 outbreak highlights critical gaps in school emergency preparedness. Brookings. Available at: https://www.brookings.edu/blog/educationplus-development/ (Accessed 26 May 2020).

Anderson, W. A. (2005). Bringing children into focus on the social science disaster research agenda. International Journal of Mass Emergencies and Disasters, 23(3), 159-175. Available at: http://ijmed.org/articles/376/download/ (Accessed 26 May 2020).

Armstrong, R. B. J., Doyle, J. and Waters, E. (2011). Cochrane Update. 'Scoping the scope' of a Cochrane review. Journal of Public Health, 33(1), 147-150. https://doi.org/10.1093/pubmed/fdr015

Bao, W. (2020). COVID -19 and online teaching in higher education: A case study of Peking University. Human Behavior and Emerging Technology, 2(2), 113-115. https://doi.org/10.1002/hbe2.191

Birkun, A. (2020). Distant learning of BLS amid the COVID-19 pandemic: Influence of the outbreak on lay trainees' willingness to attempt CPR, and the motivating effect of the training. Resuscitation. https://doi.org/10.1016/ j.resuscitation.2020.05.023

Cahapay, M. B. (2020). Rethinking education in the new normal post-COVID-19 era: A curriculum studies perspective. Aquademia, 4(2), ep20018. https://doi.org/ 10.29333/aquademia/8315

Centers for Disease Control and Prevention (2020). Coronavirus Disease 2019 (COVID-19). Available at: https://www.cdc.gov/coronavirus/2019-ncov/daily-lifecoping/children.html (Accessed 26 May 2020).

Erdogan, N. and Stuessy, C. L. (2015). Examining inclusive STEM schools' role in the college and career readiness of students in the United States: A multi-group analysis of students' achievement outcomes. Educational Sciences: Theory \& Practice, 15(6), 1517-1529. https://doi.org/ 10.12738/estp.2016.1.0072 
Gebbie, K. M., Weist, E. M., McElligott, J. E., Biesiadecki, L. A., Gotsch, A. R., Keck, C. W. and Ablah, E. (2013). Implications of preparedness and response core competencies for public health. Journal of Public Health Management and Practice, 19(3), 224-230. https://doi.org/10.1097/phh.0b013e318254cc72

Glatthorn, A., Boschee, F., Whitehead, B. and Boschee, B. (2016). Curriculum Leadership: Strategies for Development and Implementation. Thousand Oaks, California: SAGE.

Hsu, E. B., Thomas, T. L., Bass, E. B., Whyne, D., Kelen, G. D. and Green, G. B. (2016). Healthcare worker competencies for disaster training. BMC Medical Education, 6(1), 19. https://doi.org/10.1186/1472-6920-6-19

Hayes, J. L. (1979). A new look at managerial competence: the AMA model of worthy performance. Management Review, $2-3$.

Humanitarian Response (2020). What is preparedness? Available at: https://www.humanitarianresponse.info/ en/coordination/preparedness/what-preparedness (Accessed 26 May 2020).

International Association of Universities (2020, April 25). COVID-19: Higher education challenges and responses [Report]. Available at: https://www.iau-aiu.net/Covid-19Higher-Education-challenges-and-responses (Accessed 26 May 2020).

King, R. V., Burkle, F. M., Walsh, L. E. and North, C. S. (2015). Competencies for disaster mental health. Current Psychiatry Reports, 17(14), 548. https://doi.org/10.1007/ s11920-015-0548-2

Maripe, K., \& Sinkamaba, R. P. (2014). Social work education and disaster risk reduction in Botswana. International Journal of Multidisciplinary Academic Research, 2(2), 23-31. Available at: http://www.multidisciplinaryjournals.com/ wp-content/uploads/ (Accessed 26 May 2020).

Markenson. D., DiMaggio, C. and Redlener, I. (2006). Preparing health professions students for terrorism, disaster, and public health emergencies: core competencies. Academic Medicine, 80(6), 517-526. https://doi.org/10.1097/ 00001888-200506000-00002

Matton, J. (2005). Designing and developing technical curriculum: Finding the right subject matter expert. Journal of STEM Teacher Education, 42(2), 61-76. Available at: https://ir.library.illinoisstate.edu/cgi/ (Accessed 26 May 2020).

McLeod, V. (2020, March 16). COVID-19: A history of coronavirus. Lab Manager. Available at: https://www. labmanager.com/lab-health-and-safety/covid-19-ahistory-of-coronavirus-22021 (Accessed 26 May 2020).

Miller, J. M. (2020). Coronavirus (COVID-19): Social distancing with children. Kids Health. Available at: https://kidshealth. org/en/parents/coronavirus-social-distancing.html

Nelson, C., Lurie, N., Wasserman, J., \& Zakowski, S. (2007). Conceptualizing and defining public health emergency preparedness. American Journal of Public Health, 97(1), 911. https://doi.org/10.2105/AJPH.2007.114496
Ng, G. (2012) Disaster work in China: Tasks and competences for social workers. Social Work Education, 31(5), 538-556. https://doi.org/10.1080/02615479.2011.581277

Offorma, G. C. (2016). Integrating components of culture in curriculum planning. International Journal of Curriculum and Instruction 8(1), 1-8. Available at: http://www.sciedu press.com/journal/index.php/jct (Accessed 26 May 2020).

Pfefferbaum, B., Pfefferbaum, R. L. and Van Horn, R. L. (2018). Involving children in disaster risk reduction: the importance of participation. European Journal of Psychotraumatology, $\quad$ 9(sup2), 1425577. https://doi.org/10.1080/20008198.2018.1425577

Print, M. (1993). Curriculum Development and Design. Sydney: SRM Production Services.

Schultz, C. H., Koenig, K. L., Whiteside, M. and Murray, R. (2012). Development of national standardized all-hazard disaster core competencies for acute care physicians, nurses, and EMS professionals. Annals of Emergency Medicine, 59(3), 196-208. https://doi.org/10.1016/j. annemergmed.2011.09.003

Shereen, M. A., Khan, S., Kazmi, A, Bashir, N. and Siddique, R. (2020). COVID-19 infection: Origin, transmission, and characteristics of human coronaviruses. Journal of Advanced Research, 24, 91-98. https://doi.org/10.1016/ j.jare.2020.03.005

Smith, K., Jarris, P., Inglesby, T., Hatchett, R., \& Kellermann, A. (2013). Public health preparedness research. Journal of Public Health Management and Practice, 19(2), 6-8. https://doi.org/10.1097/PHH.0b013e3181c33de4

The Emily Post Institute (2020). The etiquette of social distancing during the COVID-19 pandemic. Available at: https://emilypost.com/advice/the-etiquette-of-socialdistancing-around-coronavirus/ (Accessed 26 May 2020).

Uhernik, J. (1998). The counselor and the disaster response team: An emerging role. In G. R. Walz, J.C. Bleuer, and R.K. Yep (Eds.), Compelling counseling interventions: Celebrating VISTAS' fifth anniversary (pp. 313-321). Ann Arbor, MI: Counseling Outfitters. Available at: https:/www.counsel ing.org/resources/library/vistas/ (Accessed 26 May 2020).

Valencia, M. I. C., Ali, M., Maryani, E. and Supriatna, N. (2018, September). Integration of Disaster Risk Reduction in the Curriculum of Philippine Educational Institution. Paper presented at 3rd Asian Education Symposium. Available at: https://download.atlantis-press.com/proceedings/aes18/55917397 (Accessed 26 May 2020).

Wagner, C. (2020, March 25). Kids, teens and how to stop the spread of COVID-19. Loma Linda University Health. Available at: https://news.llu.edu/health-wellness/kidsteens-and-how-stop-spread-of-covid-19 (Accessed 26 May 2020).

World Health Organization (2020). Coronavirus disease (COVID-19) advice for the public. Available at: https://www.who.int/emergencies/diseases/novelcoronavirus-2019/advice-for-public (Accessed 26 May 2020). 